\title{
Ерина И.А.
}

\section{Образ жизни студентов медицинских вузов}

ФГБОУ ВО «Астраханский государственный медиџинский университет»

(Россия, Астрахань)

doi: $10.18411 / \mathrm{j}-09-2018-76$

idsp: 000001:lj-09-2018-76

\section{Аннотация}

В статье представлено исследование формирования здорового образа жизни у студентов Астраханского медицинского университета. Исследование проводилось выборочным методом. Объем выборки - 150 студентов в возрасте 17 - 20 лет. Респондентам была предложена анкета по формированию здорового образа жизни у студентов, составленная по всем правилам маркетингового исследования. Опрос показал, что студенты, в подавляющем болышинстве (87 \%) ориентированы на необходимость поддержания и укрепления здоровья для предстоящей длительной жизни, всего, менее 4 $\%$ опрошенных определяли ее менее чем на 60 лет.

Ключевые слова: студенты, образ, формирование, здоровье, анкета,

Введение. Для подростков здоровье является главной движущей силой, на которую влияют условия жизни, биологические характеристики, культура, образ жизни, в том числе духовная, социальная, физическая и экономическая окружающая среда[2, 3, 8, 9]. Проблема сохранения и приумножения здоровья студентов приобретает чрезвычайно важное социальное значение $[1,5,6,7]$

Политика российского правительства в сфере здравоохранения в целом направлена на охрану здоровья граждан в России. Для осуществление этой задачи, используются меры, направленные на сохранение санитарно-эпидемиологического благополучия [4]

Цель исследования: исследовать формирование здорового образа жизни у студентов Астраханского медицинского университета

Материалы и методы: исследование проводилось выборочным методом. Объем выборки - 150 студентов Астраханского медицинского университета в возрасте 17 - 20 лет, из них лица мужского пола составили - 93 (62 \%) человек, женского - 57 (38 \%) человек. Средний возраст - 19,5 года. Исследование проводилось в виде анонимного анкетного опроса, являющимся результативным методом социологического исследования, который не требует особых условий и предметов, а также способный охватить наибольшее количество опрашиваемых людей. Респондентам была предложена анкета по формированию здорового образа жизни у студентов, составленная по всем правилам маркетингового исследования. Анкета содержала вопросы открытого и закрытого типа.

Результаты исследования: согласно данным опроса, 88 \% студентов принадлежали к социально-благополучным семьям, в составе которых не было алкоголиков, пьяниц, однако $72 \%$ опрошенных отметили, что в их семьях принято употребление алкоголя по праздникам и в связи разного рода торжествами, 1-2 раза в месяц или чаще. Опрос показал, что студенты, в подавляющем большинстве (87 \%) ориентированы на необходимость поддержания и укрепления здоровья для предстоящей длительной жизни, всего, менее $4 \%$ опрошенных определяли ее менее чем на 60 лет.

Однако образ жизни многих опрошенных не способствовал укреплению здоровья. Достаточно высокая активность присуща всего 55 \% опрошенных, у 34 \% являлась умеренной, а у 16 \% - низкой. Только $42 \%$ закаливаются водными процедурами, 40 \% соблюдают более или менее правильный режим питания (едят 4 раза в сутки, не уходят в вуз не позавтракав, ужинают не позднее, чем за 2 часа до сна). У $25 \%$ нарушения 
режима питания являются грубыми, явно вредящим здоровью, 35 \% опрошенных постоянно не досыпают.

Мы не смогли выявить какой-либо зависимости частоты отклонения от норм здорового образа жизни, от образовательного ценза родителей, от жилищных условий и уровня ее материального достатка. Однако студенты из социально-отягощенных семей (наличие в семье алкоголизма или пьяницы, конфликтные отношения между членами семьи) различные отклонения отмечалось в среднем 25-30\% чаще.

Условия опроса не позволяли получить абсолютно достоверных данных о подверженности опрошенных вредными привычками. Однако отметим, что курящимися себя называли 25 \% юношей и 10 \% девушек. Среди опрошенных студентов 35 (23,3\%) человек никогда не употребляли алкоголь, 16 (10,6 \%) человек пробовали его единожды и больше никогда не употребляли. Остальные 99 опрошенных студента (66 \%) употребляют алкоголь с той или иной периодичностью (примерно 1 раз в месяц или реже)

Таким образом пропаганда здорового образа жизни среди студентов нуждается в усилении. Она должна вестись на фоне их систематизированного приучения к здоровому образу жизни, основное содержание пропаганды должны составить сообщения конкретизированных сведений о влияния алкоголя и курения на организм.

$$
\text { *** }
$$

1. Волохова Н.П. Особенности влияния социального окружения студента на приобщение к здоровому образу жизни/ Н.П. Волохова // В мире научных открытий. - 2011. - № 9-1 (21). - С. 399-407.

2. Галимзянов, Х.М. Роль метода лазерной допплеровской флоуметрии в диагностике васкулитов инфекционной природы / Х.М. Галимзянов, Р.А. Садретдинов // Астраханский медицинский журнал. 2011. - T.6, № 2. - С. 241-242.

3. Грачиева, О.В. Нарушения микроциркуляторного русла у больных природно-очаговыми инфекциями / О.В. Грачиева, Р.А. Садретдинов // Проблемы особо опасных инфекций. - 2013. - № 2. - С. 78-79.

4. Мартиросова Т.А. Ориентирование студента на здоровый образ жизни в процессе профессионального становления / Т. А. Мартиросова // В мире научных открытий. - 2010. - № 4-14 (10). - С. 10-13.

5. Полунин, А.А. Сравнительный анализ фертильности у мужчин с хроническим простатитом / А.А. Полунин, В.М. Мирошников, Л.П. Воронина, Р.А. Садретдинов, В.И. Браташ, Ф.Р. Асфандияров // Астраханский медицинский журнал. - 2014. - Т.9, № 2. - С. 63-68.

6. Садретдинов, Р.А. Нарушение процессов перекисного окисления белков, липидов и антиоксидантной защиты при развитии бесплодия у больных хроническим простатитом на фоне инфекций, передающихся половым путём / Р.А. Садретдинов, О.С. Полунина, Л.П. Воронина, А.А. Полунин // Кубанский научный медицинский вестник. - 2016. - № 1 (156). - С. 121-124.

7. Садретдинов, Р.А. Анализ уровня интерлейкина-8 при хроническом простатите / Р.А. Садретдинов, А.А. Полунин, Ф.Р. Асфандияров // Международный журнал экспериментального образования. -2015. - № 3-1. - C. 69-70.

8. Садретдинов, Р.А. Изменения микрососудистого русла при инфекционных лихорадках / Р.А. Садретдинов, Х.М. Галимзянов // Астраханский медицинский журнал. - 2012. - Т.7, № 2. - С. 93-95.

9. Удовиченко О.В. Формирование здорового образа жизни студента в спортивно-педагогическом процессе вуза / О.В. Удовиченко // Запад-Россия-Восток. - 2011. - № 5. - С. 306-310.

\section{Ерина И.А. Профилактика сифилиса \\ ФГБОУ ВО «Астраханский государственный медицинский университет»} (Россия, Астрахань)

doi: $10.18411 / \mathrm{j}-09-2018-77$

idsp: 000001:lj-09-2018-77

\section{Аннотация}

В статье освещены вопросы профилактики сифилиса. В основе профилактики сифилиса лежит настороженность врачей всех специальностей, а также диспансерный метод, который осуществляется персоналом кожно-венерологических диспансеров. 